\title{
Некоторые итоги акклиматизации видов дендрофлоры Алтая в Среднем Поволжье (Самарская область)
}

\section{Some results of Altai dendfoflora species acclimation in the Middle Povolzhye (Samarskaya oblast)}

\author{
Розно С. А. ${ }^{1}$, Помогайбин А. В. ${ }^{1}$, Кавеленова Л. М. ${ }^{2}$ \\ Rozno S. A. ${ }^{1}$, Pomogaybin A. V. ${ }^{1}$, Kavelenova L. M. ${ }^{2}$ \\ ${ }^{1}$ Ботанический сад Самарского национального исследовательского университета им. академика С. П. Королева, \\ 2. Самара, Россия. E-mail:sambg@ssau.ru \\ ${ }^{2}$ Биологический факультет Самарского национального исследовательского университета им. академика \\ С. П. Королева, г. Самара, Россия.E-mail:Ikavelenova@mail.ru \\ ${ }^{1}$ Botanical Garden of Samara National Research University, Samara, Russia \\ ${ }^{2}$ Biological department of Samara National Research University, Samara, Russia
}

\begin{abstract}
Peфepam. Самарская область в Среднем Поволжье и более обширная территория Алтая при рассмотрении с позиций принципа климатических аналогов характеризуются сходством условий в силу их экотонного характера и имеют ряд общих видов дендрофлоры. Большинство видов деревьев и кустарников алтайского происхождения, для которых проводились интродукционные испытания в Ботаническом саду Самарского университета, показало высокую степень устойчивости. Приведены примеры деревьев и кустарников, успешно акклиматизированных и рекомендуемых для выращивания в регионе.
\end{abstract}

Ключевые слова. Алтай, интродукция растений, природная дендрофлора, Самарская область, устойчивость.

Summary. Samarskaya oblast (Middle Povolzhye) and larger territory of Altai compared on the base of climate analogs principle show some common features due to their ecotone specifity and have some common arboreal species. The most tree and bush species originated from Altai showed the high level of resistance during their acclimation study in the Botanical Garden of Samara University. The examples of trees and bushes successfully acclimated in Samarskaya oblast and recommended for regional greening are given in the article.

Key words. Altai, natural dendroflora, plant acclimation, resistance, Samarskaya oblast.

Классический подход в интродукции растений, базирующийся на принципе климатических аналогов (Mayr, 1909), обнаруживает сочетание совпадающих черт и некоторых различий природных условий Самарской области (часть Среднего Поволжья) и более обширного региона Алтая, принадлежащего к Алтае-Саянской макропровинции (Шумилова, 1962). Обе территории характеризуются экотонной спецификой, демонстрируя переход от лесных экосистем к степным (Алтай), либо от лесостепи к степи (Самарская область).

Для равнин Алтая отчетливо прослеживается связь с предгорными и горными ландшафтами (низкогорьями и среднегорьями Салаира и Кузнецкого Алатау с севера и северо-востока и Алтайской горной страной с юга и юго-запада) (Силантьева, 2008). Равнинная в целом Самарская область имеет на своей территории невысокий и ограниченный по площади массив Жигулевских гор.

Умеренный климат обеих территорий, демонстрирующий изменчивость показателей температуры, влажности и других параметров в суточном, сезонном и годовом плане, для Алтая характеризуется более выраженной континентальностью. Самарская область традиционно рассматривается как район рискованного земледелия из-за риска повторяющихся засух, экстремальных низких зимних температур, поздних весенних и ранних осенних заморозков. 
Алтай, по сравнению с Самарской областью, отличается большим разнообразием типов лесных сообществ, принадлежащих к нескольким высотным поясам (Шумилова, 1962; Коропачинский, Встовская, 2002). Здесь представлены ленточные и островные боры, лиственничные, березово-лиственничные и кедровые леса гор, темнохвойная тайга, еловые заболоченные леса долин рек, черневые леса с участием липы сибирской, березовые и осиновые леса, а также ивовые и тополевые леса по прирусловым частям речных долин (Силантьева, 2008). Тем не менее специалисты отмечают для данной обширной территории сравнительную бедность видового состава дендрофлоры - до 175 видов растений, относящихся к древесным и полудревесным жизненным формам (Силантьева, 2008).

Ряд видов дендрофлоры характерен для территории Алтая в целом (тополь черный - Populus nigra L., осина - P. tremula L., береза повислая - Betula pendula Roth., ива белая - Salix alba L., ива серая - S. cinerea L., боярышник кровяно-красный - Crataegus sanguinea L., калина обычновенная Viburnum opulus L. и др.) - как правило, это виды, характеризующиеся широким распространением за пределами Алтая. Представлены также виды деревьев и кустарников, имеющие ограниченное распространение, в том числе эндемичного характера.

Что касается природной дендрофлоры Самарской области, ее состав - более 60 видов деревьев и кустарников, среди которых преобладают лиственные листопадные виды, аборигенные хвойные представлены 3 видами - сосна обыкновенная Pinus sylvestris L. и два вида можжевельников - Juniperus communis L., J. sabina L., исключительно редко встречающихся и занесенных в областную Красную книгу (Плаксина, 2001; Флора ..., 2007). С учетом интродуцентов, используемых в различных типах насаждений, объем дендрофлоры к настоящему времени фактически превышает 170 видов (Розно, 2005), а в последнее время активно растет за счет форм и сортов.

Характерно, что целый ряд древесных видов является общим для этих двух географически отдаленных территорий. К ним в первую очередь принадлежат, например, среди деревьев - сосна обыкновенная (Pinus sylvestris L.), береза повислая (Betula pendula Roth.), тополь черный (Populus nigra L.), осина (P. tremula L.), ива белая (Salix alba L.), ива козья (S. caprea L.), ива серая (S. cinerea L.), среди кустарников - кизильник черноплодный (Cotoneraster melanocarpa Lodd.), спирея городчатая (Spirea crenata L.), спирея зверобоелистная (S. hypericifolia L.) и др., которым присущи широта ареалов и высокая экологическая пластичность.

Интродукционные испытания древесных видов разного географического происхождения, в том числе произрастающих на Алтае, были проведены в Ботаническом саду Самарского университета в значительном объеме и захватили период с 50-х годов XX в. по настоящее время. Древесные интродуценты, прошедшие акклиматизацию в новых условиях обитания, представляют собой ценный резерв для формирования искусственных насаждений и приобретают возможности сохраняться в форме популяционных групп вне природного ареала в целях их охраны ex situ.

Большинство таксонов алтайского происхождения показало высокую степень устойчивости в районе интродукции, наиболее существенным стрессом для них выступали экстремальные засухи, как правило, не вызывавшие выпадения растений. Периодически отмечающиеся в регионе экстремально низкие зимние температуры в меньшей степени повреждали растения, которые в природных условиях испытывают подобные воздействия. В качестве примера успешно прошедших акклиматизацию видов имеются как кустарники - виды рода Spiraea L., сибирея алтайская (Sibiraea altaensis (Laxm.) Schneid.), лапчатка кустарниковая (Pentaphylloides fruticosa (L.) Rydb.), так и деревья - Crataegus chlorocarpa Lenne et C. Koch (C. altaica) и др. Данные растения размножаются и используются для пополнения экспозиций сада, а также внедряются в городское озеленение. Сорта Pentaphylloides fruticosa с различной окраской лепестков предлагаются населению.

Широкое распространение во флоре Алтая кустарников, дающих ценную по витаминному составу плодовую продукцию, давно привлекло внимание специалистов к Hippophae rhamnoides L., Lonicera altaica Pall., L. caerulea L., для которых уже существует множество сортов. Для условий Caмарской области данные растения можно считать прошедшими акклиматизацию, главное условие их устойчивого роста - регулярный полив в засуху.

Ценное хвойное растение Алтая - сосна сибирская (Pinus sibirica Du Tour), для которой неоднократно предпринимались попытки внедрения в насаждения Самарской области, пока не получила 
широкого распространения. В начале своего развития в местных условиях данный вид особо чувствителен к засухе и нуждается в поливе. В дендрарии Ботанического сада экземпляры сосны сибирской начали плодоношение в возрасте 17 лет. В Красноярском лесничестве Самарской области имеется небольшая делянка плодоносящих кедровых сосен, привитых на сосну обыкновенную.

Растения, выращенные из семян алтайского происхождения, обычно оказываются устойчивыми к условиям лесостепи Самарской области, а также при выполнении агротехнических мероприятий (полив) могут рекомендоваться для насаждений в степных районах. В перспективе желательно продолжить работу по интродукции видов дендрофлоры Алтая, обращая особое внимание на узко распространенные и эндемичные. Интерес представляют также семена хвойных из различных природных биотопов Алтая, которые можно использовать для получения экземпляров, более устойчивых к условиям лесостепи Среднего Поволжья. Они представляют многообещающий материал для дальнейших интродукционных испытаний и последующего введения в культуру: это деревья (Abies sibirica Ledeb., Larix sibirica Ledeb. из лесостепных местообитаний...), так и кустарники (алтайские виды рода Juniperus L., Lonicera L., Caragana Lam.).

Это будет способствовать сохранению ценных видов природной флоры вне ареала естественного произрастания и расширению ассортимента растений, вовлекаемых в культуру.

\section{ЛИТЕРАТУРА}

Коропачинский И. Ю., Встовская Т. И. Древесные растения Азиатской России. - Новосибирск: Изд-во СО РАН, филиал «Гео», 2002. - 707 с.

Плаксина Т. И. Конспект флоры Волго-Уральского региона. - Самара: Самарский университет, 2001. - 388 с. $\boldsymbol{P o з н о} \boldsymbol{C}$. A. Эколого-биологический анализ итогов интродукции древесных растений в лесостепи Среднего Поволжья: Авторефер. дисс. ...кандидата биол. наук. - Самара, 2005. - 20 с.

Силантьева М. М. Флора Алтайского края: анализ и история формирования: Авторефер. дисс. ... доктора биол. наук. - Новосибирск, 2008. -35 с.

Флора Самарской области / под ред. А. А. Устиновой, Н. С. Ильиной. - Самара: Изд-во СГПУ, 2007. - 321 с. Шумилова Л. В. Ботаническая география Сибири. - Томск, 1962. - 440 с.

Mayr H. Waldbau auf naturgeschichtlicher Grundlage. - Berlin, 1909. - 568 s. 